\title{
Skeptisme Profesional, Independensi dan Pengungkapan Kecurangan: Studi pada Hotel di Kabupaten Badung
}

\author{
I Putu Eka Mertanaya \\ Fakultas Ekonomi dan Bisnis \\ Universitas Udayana, Indonesia
}

\author{
I Dewa Nyoman Wiratmaja \\ Fakultas Ekonomi dan Bisnis \\ Universitas Udayana, Indonesia
}

\section{ABSTRAK}

Pengungkapan fraud yang baik terjadi apabila pengawas internal sebagai auditor memiliki aspek yang mendukung proses pengungkapan fraud. Penelitian ini bertujuan untuk mengetahui pengaruh skeptisme profesional dan independensi pada pengungkapan fraud. Penelitian ini dilakukan pada hotel berbintang 3 ke atas di Kabupaten Badung Selatan dengan jumlah hotel yang berpartisipasi sebanyak 11 hotel. Teknik yang digunakan yaitu teknik purposive sampling yang termasuk dalam nonprobability sampling. Metode pengumpulan data dengan melakukan kuesioner dan metode analisis data menggunakan metode regresi linear berganda. Hasil penelitian ini menunjukkan bahwa skeptisme profesional tidak berpengaruh signifikan pada pengungkapan fraud dan independensi berpengaruh signifikan pada pengungkapan fraud. Kurangnya skeptis yang dimiliki pengawas internal karena adanya sikap saling percaya dengan rekan kerja. Baik perusahaan swasta ataupun negeri, pihak auditor dalam suatu perusahaan tetap mempertahankan independensinya dalam melakukan proses audit.
\end{abstract}

Surel : mertanaya@yahoo.co.id

$\begin{array}{ll}\text { Kata Kunci: } & \begin{array}{l}\text { Skeptisme Profesional; Independensi; } \\ \text { Pengungkapan Fraud. }\end{array}\end{array}$

\section{Professional Skepticism, Independence and Fraud} Disclosure: A Study on Hotels in Badung Regency

\section{ABSTRACT}

Good fraud disclosure occurs when the internal supervisor as an auditor has aspects that support the fraud disclosure process. This study aims to determine the effect of professional skepticism and independence on fraud disclosure. This research was conducted at 3-star hotels and above in South Badung Regency with a total of 11 participating hotels. The technique used is purposive sampling technique which is included in nonprobability sampling. Data collection methods by conducting questionnaires and data analysis methods using multiple linear regression methods. The results of this study indicate that professional skepticism has no significant effect on disclosure of fraud and independence has a significant effect on disclosure of fraud. The lack of skepticism internal supervisors have due to mutual trust with coworkers. Both private and state companies, the auditors in a company still maintain its independence in conducting the audit process.

Keywords: Professional Skepticism; Independence; Fraud Disclosures.

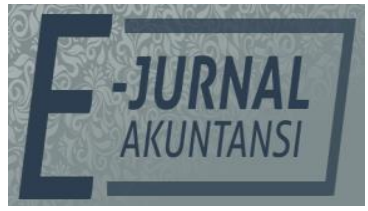

e-ISSN 2302-8556

Vol. 30 No. 11

Denpasar, Nopember 2020

Hal. 2892-2906

DOI:

10.24843/EJA.2020.v30.i11.p14

PENGUTIPAN:

Mertanaya, I P.E. \&

Wiratmaja, I D.N. (2020).

Skeptisme Profesional,

Independensi dan

Pengungkapan Kecurangan:

Studi pada Hotel di

Kabupaten Badung. E-Jurnal

Akuntansi, 30(11), 2892-2906

RIWAYAT ARTIKEL:

Artikel Masuk:

5 April 2020

Artikel Diterima:

14 Juli 2020

Artikel dapat diakses : https://ojs.unud.ac.id/index.php/Akuntansi/index 


\section{PENDAHULUAN}

Perkembangan perekonomian dan teknologi saat ini tidak hanya memberikan dampak positif bagi kemajuan perekonomian negara namun juga dapat menjadi ancaman balik terhadap perekonomian negara karena adanya beberapa tindakan kecurangan (fraud). Menurut Arens (2012) dalam Andriyanti (2019) Kecurangan merupakan bentuk penyimpangan atau perbuatan yang melanggar hukum yang dilakukan secara sengaja, untuk keuntungan pribadi atau kelompok, secara langsung dan tidak langsung merugikan pihak lain. Dalam membuat laporan audit mengenai laporan keuangan perusahaan yang baik pengawas internal harus berpegang teguh terhadap dua faktor dari diri pengawas internal tersebut antara lain skeptisme profesional dan independensinya. Skeptisme profesional adalah sikap kritis dan berhati-hati dalam menganalisis bukti-bukti yang dikumpulkan untuk menilai kewajaran laporan keuangan. Sifat independensi adalah cara pandang yang tidak memihak di dalam pelaksanan pengujian, evaluasi hasil pemeriksaan dan penyusunan laporan audit (Arens, 2012). Berdasarkan Keputusan Menteri Parpostel No KM 94/HK103/MPPT 1987 pengertian hotel adalah salah satu jenis akomodasi yang mempergunakan sebagian atau keseluruhan bagian untuk jasa pelayanan penginapan, penyedia makanan dan minuman serta jasa lainnya bagi masyarakat umum yang dikelola secara komersil. Kecurangan yang terjadi di dunia pariwisata (perhotelan) dapat dilakukan secara perorangan dan kelompok.

Penelitian ini merupakan adopsi dari penelitian yang dilakukan oleh Purwanti (2017) dengan topik Pengaruh Auditor's Professional Skepticism, Red Flags, Beban Kerja Pada Kemampuan Auditor Dalam Mendeteksi Fraud (Studi Empiris pada Kantor Akuntan Publik Provinsi Bali). Perbedaan penelitian ini dengan penelitian sebelumnya adalah variabel red flag dan beban kerja diubah dengan variabel independensi, serta lokasi penelitian yang dilakukan di Kantor Akuntan Publik diubah dengan Hotel Berbintang 3 Ke Atas Di Kabupaten Badung Selatan. Alasan peneliti menggunakan variabel independensi dan lokasi penelitian adalah hotel karena peneliti terdorong untuk menguji pengaruh sifat skeptis dan independensi dari seorang pengawas internal yang menjalankan fungsi auditor yang mana sebagai pekerja, pengawas internal mendapatkan penghasilan dari organisasi dimana dia bekerja.

Disini konflik audit muncul ketika pengawas internal menjalankan aktivitas audit internal. Pengawas internal sebagai pekerja di dalam organisasi yang diauditnya akan mengalami masalah ketika harus melaporkan temuantemuan yang mungkin tidak menguntungkan dalam penilaian kinerja manajemen atau objek audit yang dilakukannya. Jika pengawas internal diminta untuk melanggar kode etik mereka atau standar praktik profesional maka pengawas tersebut akan kehilangan kredibilitas yang dimilikinya sedangkan menolak permintaan klien bisa menyebabkan pengawas internal kehilangan pekerjaan mereka (Sawyer, 2005). Penelitian ini bertujuan untuk meneliti Pengaruh Skeptisme Profesional Dan Independensi Pada Pengungkapan Fraud (Studi Empiris Pada Pengawas Internal Hotel Berbintang 3 Ke Atas Di Kabupaten Badung Selatan).

Terdapat teori yang digunakan dalam penelitian ini antara lain Theory of Planned Behavior, Attribution Theory, Fraud Tree Theory dan Fraud Triangle Theory. 
Menurut Suryanto (2017) menggambarkan bahwa Teori Perilaku yang Direncanakan (Theory of Planned Behavior) adalah teori yang mengasumsikan bahwa manusia akan berperilaku sesuai dengan apa yang diinginkan oleh lingkungannya. Menurut Heider (1958) teori atribusi (Attribution Theory) merupakan suatu teori yang menjelaskan tentang penyebab atau motif seseorang baik dari faktor internal maupun eksternal yang memberikan pengaruh untuk melakukan suatu tindakan atau perilaku. Menurut Susilawati (2014) dalam Andriyanti (2019) Association of Certified Fraud Examiner (ACFE) mendefinisikan kecurangan sebagai tindakan mengambil keuntungan secara sengaja dengan cara menyalahgunakan suatu pekerjaan/jabatan atau mencuri asset/sumber daya dalam organisasi. Menurut Cressey (1953) mendefinisikan teori segitiga kecurangan (Fraud Triangle Theory) adalah teori yang mengambarkan tiga faktor utama pendorong seseorang melakukan tindakan kecurangan.

Menurut Arens (2012) audit merupakan proses pengumpulan dan penilain bukti atau pengevaluasian bukti mengenai informasi untuk menentukan dan melaporkan tingkat kesesuain antara informasi tersebut dan kriteria yang ditetapkan. Audit harus dilakukan oleh orang yang kompeten dan independen. Secara umum audit memiliki tujuan untuk menyatakan pendapat yang berkaitan dengan kewajaran atas semua hal yang material, posisi keuangan dan hasil usaha serta arus kas sesuai dengan prinsip yang berlaku (Halim, 2003:147). Secara umum kegiatan audit dapat dibagi menjadi 3 yaitu audit operasional, audit ketaatan, dan audit laporan keuangan.

Menurut Jurnal Kementerian Dalam Negeri (2010) dalam Ponamon (2014) Pengawasan adalah suatu upaya yang sistematik untuk menetapkan kinerja standar pada perencanaan untuk merancang sistem umpan balik informasi, untuk membandingkan kinerja aktual dengan standar yang telah ditentukan, untuk menetapkan apakah telah terjadi suatu penyimpangan tersebut, serta untuk mengambil tindakan perbaikan yang diperlukan untuk menjamin bahwa semua sumber daya perusahaan atau pemerintahan telah digunakan seefektif dan seefisien mungkin guna mencapai tujuan perusahaan atau pemerintahan. Pengawas internal dalam perhotelan terdiri dari bagian auditor internal (Night Auditor dan Income Auditor), akuntan (Chief Accountant dan Cost Control), dan perpajakan (Taxer).

Dalam SA 240 yang diterbitkan oleh Institut Akuntan Publik Indonesia (IAPI) (2012), dijelaskan bahwa auditor yang melaksanakan audit berdasarkan SA bertanggung jawab untuk memperoleh keyakinan memadai apakah laporan keuangan secara keseluruhan bebas dari kesalahan penyajian material yang disebabkan oleh kecurangan atau kesalahan. Dalam SA 315 yang diterbitkan oleh Institut Akuntan Publik Indonesia (IAPI) (2012) menyatakan bahwa auditor bertanggung jawab untuk mengidentifikasi dan menilai risiko kesalahan penyajian material dalam laporan keuangan, melalui pemahaman atas entitas dan lingkungannya, termasuk pengendalian internal entitas. Pengawas internal dalam melakukan proses audit memerlukan pemahaman mengenai standar operasional dari perusahaan serta peraturan yang berlaku di perusahaan tersebut. Pola kerja dari pegawai di lingkungan perusahaan juga dapat mempengaruhi suatu proses audit dengan adanya hubungan pertemanan sehingga mengurangi sikap skeptis 
dari pengawas internal sehingga dapat mengurangi kemampuan pengawas tersebut mengungkapkan fraud.

Penelitian yang dilakukan oleh Biksa dan Wiratmaja, (2016) mengatakan bahwa skeptisme profesional auditor berpengaruh positif pada pendeteksian kecurangan pada KAP dapat diterima. Terdapat juga penelitian yang dilakukan oleh Hartan (2016) mengatakan bahwa Skeptisme Profesional memiliki pengaruh positif dan signifikan terhadap Kemampuan Auditor Mendeteksi Kecurangan pada Inspektorat Daerah Istimewa Yogyakarta. Berdasarkan uraian tersebut, maka dapat dirumuskan hipotesis sebagai berikut.

$\mathrm{H}_{1}$ : Skeptisme profesional berpengaruh positif dan signifikan pada kemampuan auditor mengungkapkan fraud.

Penelitian yang dilakukan oleh Hartan (2016) mengatakan bahwa Independensi berpengaruh positif dan signifikan terhadap Kemampuan Auditor Mendeteksi Kecurangan pada Inspektorat Daerah Istimewa Yogyakarta. Terdapat juga penelitian yang dilakukan oleh Tobe (2017) mengatakan bahwa Independensi Auditor berpengaruh signifikan terhadap pendeteksian kecurangan pada Kantor Akuntan Publik (KAP) di Kota Bandung. Berdasarkan uraian tersebut, maka dapat dirumuskan hipotesis sebagai berikut.

$\mathrm{H}_{2}$ : Independensi berpengaruh positif dan signifikan pada kemampuan auditor mengungkapkan fraud.

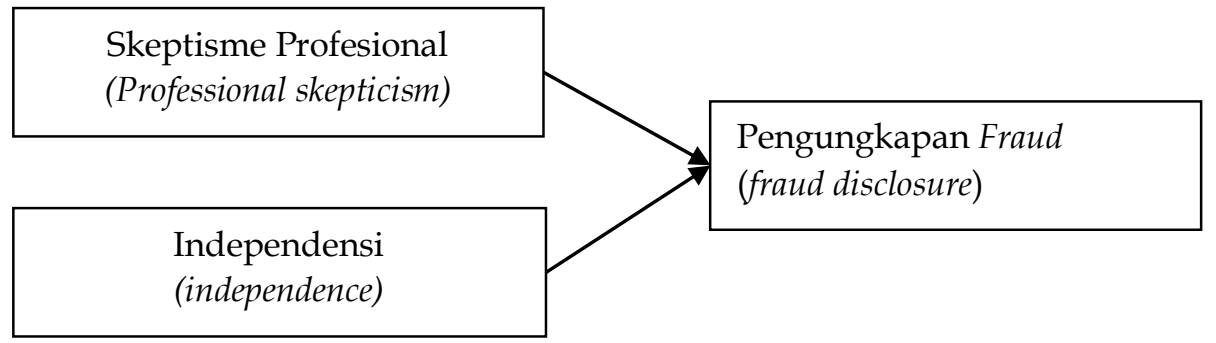

Sumber: Data Penelitian, 2020

Gambar 1. Keranganka Konseptual

\section{METODE PENELITIAN}

Penelitian ini menggunakan penelitian kausal komparatif dengan ciri-ciri ex post facto yang menurut Sugiyono (2016) yaitu penelitian untuk meneliti hubungan sebab-akibat dengan variabel yang sudah terjadi di masa lalu. Menurut Suryabrata (2006) dalam Ivana (2018) pada penelitian ex post facto, peneliti mengumpulkan data berdasarkan kenyataan atau yang terjadi di lapangan.

Peneliti menggunakan satu atau lebih dari satu variabel independen dan sebuah variabel dependen serta sebuah variabel moderasi bila diperlukan untuk menguji data tersebut dengan menelusuri kembali dengan variabel yang serupa pada periode sebelumnya untuk mencari pengaruhnya, saling keterhubungan dan maknanya. Lokasi Penelitian ini adalah pada hotel berbintang 3 ke atas di Kabupaten Badung Selatan.

Pemilihan lokasi penelitian pada hotel berbintang 3 (tiga) ke atas didasarkan pada pertimbangan bahwa hotel berbintang 3 (tiga) ke atas memiliki sistem usaha yang lengkap yaitu usaha jasa penginapan kamar, usaha manufaktur yaitu penyediaan makanan dan minuman, serta usaha dagang yaitu butik dan 
distro pakaian.Berikut merupakan daftar hotel yang berpartisipasi dalam pengisian kuesioner penelitian beserta alamatnya.

\section{Tabel 1. Daftar Hotel Responden}

\begin{tabular}{|c|c|c|}
\hline \multicolumn{3}{|r|}{ Daftar Nama Hotel } \\
\hline No. & Nama Hotel & Alamat \\
\hline 1 & Rama Residence Padma & Jl. Padma, Legian-Kuta Bali, Indonesia, 80361 \\
\hline 2 & $\begin{array}{l}\text { Kuta Puri Bungalows and } \\
\text { Spa }\end{array}$ & Popies Lane I Kuta, Kuta, Bali, Indonesia, 80361 \\
\hline 3 & Massa'Inn Hotel & Popies Lane I/27, Kuta, Bali Indonesia, 80361 \\
\hline 4 & $\begin{array}{l}\text { Rama Residence Petitenget } \\
\text { Hotel }\end{array}$ & $\begin{array}{l}\text { Jl. Raya Petitenget } 35 \text { Banjar Umasari, Seminyak, } \\
\text { Kuta, Bali, Indonesia, } 80361\end{array}$ \\
\hline 5 & $\begin{array}{l}\text { Rama Beach Resort and } \\
\text { Villa }\end{array}$ & $\begin{array}{l}\text { Jl. Jenggala, Tuban, Kuta, Bali, Badung, Bali, } \\
\text { Indonesia, } 80361\end{array}$ \\
\hline 6 & Rama Garden Hotel & Jl. Padma, Legian, Kuta, Bali, Indonesia, 80361 \\
\hline 7 & Ramayana Suites & $\begin{array}{l}\text { Jl. Bakung Sari, Kuta, Badung, Bali, Indonesia, } \\
80361\end{array}$ \\
\hline 8 & $\begin{array}{l}\text { Kuta Seaview Boutique } \\
\text { Resort and Spa }\end{array}$ & $\begin{array}{l}\text { Jl. Pantai Kuta, Kuta, Badung, Bali, Indonesia, } \\
80361\end{array}$ \\
\hline 9 & $\begin{array}{l}\text { Wyndham Dreamland } \\
\text { Resort Bali }\end{array}$ & $\begin{array}{l}\text { Kawasan Pecatu Indah, Jl. Pantai Dreamland, } \\
\text { Uluwatu, Kuta, Bali, Indonesia, } 80364\end{array}$ \\
\hline 10 & J4 Hotel Legian & $\begin{array}{l}\text { Jl. Raya Legian } 74 \text { Banjar Pengabetan, Legian, } \\
\text { Kuta, Bali, Indonesia, } 80361\end{array}$ \\
\hline 11 & La'Walon Hotel & $\begin{array}{l}\text { Jl. Popies Lane 1, Legian, Kuta, Bali, Indonesia, } \\
80361\end{array}$ \\
\hline
\end{tabular}

Sumber: Data Penelitian, 2020

Objek Penelitian dalam penelitian ini adalah pengaruh skeptisme profesional dan independensi pada pengungkapan fraud. Variabel bebas dalam penelitian ini adalah skeptisme profesional dan independensi pengawas internal. Variabel terikat dalam penelitian ini yaitu pengungkapan fraud.

Variabel yang digunakan dalam penelitian ini yaitu skeptisme profesional, independensi sebagai variabel bebas dan pengungkapan fraud sebagai variabel terikat. American Institute of Certified Public Accountants (AICPA), (2002) mendefinisikan skeptisme profesional merupakan sikap yang menggambarkan pikiran yang selalu bertanya dan penilaian kritis atas bukti audit tanpa obsesif mencurigakan atau skeptis. Menurut Jusup (2014:170) menyatakan bahwa skeptisme profesional adalah suatu sikap yang mencakup suatu pikiran yang selalu mempertanyakan, waspada terhadap kondisi yang dapat mengindikasikan kemungkinan kesalahan penyajian, baik yang disebabkan oleh kecurangan maupun kesalahan, dan penilaian penting atas suatu bukti audit. Beberapa indikator dalam menentukan sifat skeptisme profesional yang dimiliki seseorang yaitu pemikiran yang selalu bertanya, penundaan keputusan, pencarian pengetahuan, pemahaman interpersonal, dan keteguhan hati.

Menurut Mulyadi (2010) Independensi dapat diartikan sikap mental yang bebas dari pengaruh, tidak dikendalikan oleh pihak lain, tidak tergantung pada orang lain. Christiawan, (2002) juga menyatakan bahwa seorang akuntan sebagai pengawas internal berkewajiban untuk jujur kepada seluruh pihak yang berkepentingan yang telah meletakkan kepercayaan atas pekerjaannya. Beberapa 
indikator dalam menentukan sifat independensi yang dimiliki seseorang yaitu independensi dalam kenyataan, independensi dalam penampilan, dan independensi dalam pengetahuan.

Menurut Kamus Akuntansi dalam Wijaya (2016), pengungkapan/penjelasan (disclosure) adalah informasi yang diberikan sebagai lampiran/pelengkap bagi laporan keuangan, dalam bentuk catatan kaki atau tambahan. Pengungkapan fraud adalah informasi yang diberikan oleh pengawas internal sebagai pelengkap dari laporan keuangan yang menjelaskan bahwa pengawas internal dapat menemukan kesalahan penyajian data yang mengindikasikan terjadinya tindakan kecurangan. Beberapa indikator dalam menentukan kemampuan mengungkapkan kecurangan yang dimiliki seseorang yaitu pengetahuan terhadap kecurangan dan kesanggupan dalam meneliti dan mengungkapkan kecurangan.

Jenis data yang digunakan dalam penelitian ini adalah data kualitatif yang dikuantitatifkan. Data kualitatif yang dikuantitatifkan adalah data yang bersifat kualitas/sifat yang diungkapkan dengan menggunakan bilangan kuantitas. Data kualitatif yang dikuantitatifkan dalam penelitian ini diperoleh dengan hasil scoring dari jawaban para responden terhadap kuesioner yang telah dibagikan.

Sumber data yang digunakan dalam penelitian ini berdasarkan sumber data primer. Data primer dalam penelitian ini berupa jawaban dari responden atas pernyataan kuesioner yang disebarkan di 11 hotel berbintang 3 ke atas di Kabupaten Badung menurut perusahaan travel Traveloka tahun 2019 serta wawancara dengan beberapa narasumber terpercaya di dalam ruang lingkup perhotelan.

Menurut Sugiyono (2016) populasi adalah wilayah generalisasi atau umum yang terdiri atas objek/subjek yang memiliki kualitas dan karateristik tertentu yang telah ditetapkan oleh peneliti untuk dipelajari, dilakukan pengujian dan kemudian ditarik kesimpulannya. Populasi dalam penelitian ini adalah seluruh pengawas internal yang bekerja pada hotel berbintang 3 ke atas di Kabupaten Badung Selatan yang tercatat dalam perusahaan Traveloka.

Menurut (Sugiyono, 2016) sampel adalah bagian atau beberapa objek/subjek dengan jumlah dan karakteristik tertentu yang dimiliki dari populasi yang diteliti. Pengambilan sampel berarti mengambil sebagian atau beberapa objek/subjek dari populasi untuk menggambarkan populasi secara keseluruhan atau representatif. Sampel dari penelitian ini adalah pengawas internal yang bekerja pada 11 (sebelas) hotel berbintang 3 (tiga) ke atas di Kabupaten Badung Selatan dengan lama bekerja minimal 2 tahun dan memiliki riwayat pendidikan akhir minimal SMA/SLTA yang tercatat pada Badan Pusat Statistik Provinsi Bali dan terdaftar dalam perusahaan Traveloka.

Metode penentuan sampel yang digunakan dalam penelitian ini adalah purposive sampling yang merupakan salah satu teknik nonrandom sampling. Kriteria sampel dalam penelitin ini adalah pengawas internal yang bekerja paling singkat 2 (dua) tahun dan memiliki tingkat pendidikan akhir minimal tamatan SMA/SLTA pada 11 (sebelas) hotel berbintang 3 (tiga) di Kabupaten Badung Selatan yang tercatat pada Badan Pusat Statistik Provinsi Bali dan terdaftar pada perusahaan travel Traveloka tahun 2019. 
Berikut merupakan data jabatan yang dimiliki oleh responden dalam penelitian ini sebagai berikut.

\section{Tabel 2. Daftar Jabatan Responden}

\begin{tabular}{lllllllll}
\hline No. & Nama Hotel & NA1 & NA2 & IA & CC & CA & Taxer & $\begin{array}{l}\text { Jumlah } \\
\text { Auditor }\end{array}$ \\
\hline 1 & $\begin{array}{l}\text { Rama Residence Padma } \\
\text { Kuta Puri Bungalows and }\end{array}$ & 1 & 1 & 1 & 1 & 1 & & 5 \\
2 & $\begin{array}{l}\text { Spa } \\
\text { Massa'Inn Hotel }\end{array}$ & 1 & 1 & 1 & 1 & 1 & & 5 \\
3 & $\begin{array}{l}\text { Rama Residence Petitenget } \\
4\end{array}$ & 1 & 1 & 1 & 1 & 1 & 1 & 6 \\
& $\begin{array}{l}\text { Hotel Bama Beach Resort and } \\
5\end{array}$ & 1 & 1 & 1 & 1 & 1 & 1 & 6 \\
6 & Villa Rama Garden Hotel & 1 & 1 & 1 & 1 & 1 & 1 & 6 \\
7 & $\begin{array}{l}\text { Ramayana Suites } \\
\text { Kuta Seaview Boutique }\end{array}$ & 1 & 1 & 1 & 1 & 1 & 1 & 6 \\
8 & $\begin{array}{l}\text { Resort and Spa } \\
\text { Wyndham Dreamland }\end{array}$ & 1 & 1 & 1 & 1 & 1 & 1 & 6 \\
9 & $\begin{array}{l}\text { Resort Bali } \\
\text { J4 Hotel Legian }\end{array}$ & 1 & 1 & 1 & 1 & 1 & & 5 \\
11 & $\begin{array}{l}\text { La'Walon Hotel } \\
\text { Jumlah }\end{array}$ & 1 & 1 & 1 & 1 & 1 & & 5 \\
\hline
\end{tabular}

Sumber: Data Penelitian, 2020

Metode pengumpulan data yang digunakan dalam penelitian ini adalah dengan menggunakan media kuesioner untuk memperoleh data yang relevan. Kuesioner disebarkan kepada pengawas internal hotel berbintang 3 di Kabupaten Badung Selatan. Dengan menggunakan skala likert, jawaban pilihan responden akan diberi nilai untuk pernyataan sangat tidak setuju 1 poin, tidak setuju 2 poin, netral 3 poin, setuju 4 poin, dan sangat setuju 5 poin.

Pengujian instrument dalam penelitian ini menggunakan teknik uji validitas dan uji reliablitias. Uji validitas digunakan untuk mengukur valid atau tidaknya suatu kuesioner (Ghozali, 2016). Suatu kuesioner dikatakan valid jika pertanyaan pada suatu kuesioner mampu menjelaskan sesuatu yang akan diteliti dalam penelitian tersebut.

Uji reliabilitas digunakan untuk menggambarkan seberapa besar kemampuan suatu instrumen penelitian dapat dipercaya sebagai alat untuk pengumpulan data. Suatu instrumen dikatakan terpercaya jika jawaban seseorang terhadap pertanyaan adalah konsisten atau stabil dari waktu ke waktu.

Analisis statistik deskriptif adalah sebuah statistik yang menjelaskan, mengidentifikasi, dan menggambarkan suatu data dilihat dari nilai minimum, maksimum, rata-rata, dan standar deviasi.

Uji normalitas bertujuan untuk menguji apakah dalam sebuah model regresi, variabel terikat dan variabel bebas atau keduanya memiliki distribusi normal atau tidak.

Uji Multikolinearitas bertujuan untuk menguji apakah dalam model regresi terdapat hubungan multikolinearitas antara variabel bebas (independen) atau tidak. 
Uji Heteroskedastisitas bertujuan untuk menguji apakah dalam model regresi terjadi ketidaksamaan variance dari residual satu pengamatan ke pengamatan lainnya.

Pengujian Analisis Regresi Linear Berganda ini dilakukan dengan menggunakan Statistical Product and Service Solution (SPSS) 21 For Windows dengan tingkat signifikasi 5\% $(\alpha=0,05)$. Dalam menguji hipotesis dikembangkan suatu persamaan untuk menyatakan hubungan antara variabel dependen, yaitu pengungkapan fraud ( $\mathrm{Y}$ ) dengan variabel independen, yaitu skeptisme profesional (X1) dan independensi (X2). Pengujian hipotesis dengan analisis regresi linear berganda diformulasikan sebagai berikut:

$$
\begin{aligned}
& \hat{Y}=a+b_{1} X_{1}+b_{2} X_{2}+\varepsilon \\
& \text { Keterangan: } \\
& \text { Ý = Pengungkapan Fraud } \\
& \text { a } \quad=\text { Nilai Konstanta } \\
& \mathrm{X}_{1} \quad=\text { Skeptisme Profesional } \\
& \mathrm{X}_{2} \quad=\text { Independensi } \\
& \mathrm{b}_{1} \text { dan } \mathrm{b}_{2} \quad=\text { Koefisien regresi variabel independen } \\
& \varepsilon=\text { Standar error }
\end{aligned}
$$

Uji $\mathrm{F}$ adalah penguji untuk mengetahui apakah variabel bebas yang dimasukkan dalam model dapat menerangkan variasi dari variabel terikat (Ghozali, 2016). Uji F yang digunakan pada penelitian ini menggunakan signifikansi 5\% $(0,05)$.

Koefisien determinasi (Adjusted $R^{2}$ ) adalah pengujian untuk mengukur seberapa kuat kemampuan variabel independen dalam menerangkan variasi variabel dependen.

Uji hipotesis pada dasarnya menunjukkan seberapa kuat pengaruh sebuah variabel independen secara individual dalam menerangkan variasi variabel dependen (Ghozali, 2016). Uji ini dilakukan dengan membandingkan nilai thitung dengan $t_{\text {tabel }}$ sebesar 2,002 dan tingkat signifikansi masing-masing variabel bebas dengan taraf signifikansi $a=0,05$.

\section{HASIL DAN PEMBAHASAN}

Kuesioner penelitian ini disebarkan pada hotel-hotel yang terdapat di Kabupaten Badung Selatan dengan tingkat akreditas berbintang 3 ke atas. Setelah dilakukan penyebaran kuesioner didapat 11 (sebelas) hotel dengan 60 orang responden yang bersedia berpartisipasi dalam penelitian ini. Berikut adalah data kuesioner yang berhasil disebar dan kembali.

Tabel 3. Data Penyebaran Kuesioner

\begin{tabular}{lll}
\hline Keterangan & Jumlah & Persentase \\
\hline Kuesioner yang disebar & 60 & $100 \%$ \\
Kuesioner yang kembali & 60 & $100 \%$ \\
\hline
\end{tabular}

Sumber: Data Penelitian, 2020

Analisis statistik deskriptif yang tercantum dalam penelitian ini adalah analisis tabulasi data untuk setiap variabel menurut pernyataan responden dengan memberikan skor pada kuesioner yang dibagikan. Analisis ini digunakan untuk mengetahui tingkat kemampuan yang dimiliki oleh seorang setiap responden dalam sebuah pernyataan dengan memperhatikan skor yang dipilih 
dengan jawaban rata-rata keseluruhan responden. Berikut statistik deskriptif untuk variabel skeptisme profesional, independensi, dan pengungkapan fraud.

Pada Tabel 4, dapat diketahui nilai rata-rata untuk tiap pernyataan yang didapat dari total skor responden pada sifat skeptisme profesional. Untuk pernyataan responden yang memiliki skor diatas skor rata-rata dapat dikatakan bahwa pengawas internal tersebut memiliki sifat skeptisme profesional yang tinggi.

Tabel 4. Analsis Statistik Deskriptif

\begin{tabular}{llllllll}
\hline & \multicolumn{7}{c}{ Skeptisme Profesional } \\
\hline Kategori Pernyataan & STS & TS & N & S & SS & TOTAL & Rata-rata \\
\hline X1.1 & 1 & 5 & 8 & 28 & 18 & 60 & 3.95 \\
X1.2 & 1 & 0 & 3 & 34 & 22 & 60 & 4.27 \\
X1.3 & 0 & 6 & 10 & 34 & 10 & 60 & 3.8 \\
X1.4 & 0 & 0 & 2 & 34 & 24 & 60 & 4.37 \\
X1.5 & 0 & 2 & 1 & 31 & 26 & 60 & 4.35 \\
X1.6 & 1 & 0 & 2 & 22 & 35 & 60 & 4.5 \\
X1.7 & 0 & 0 & 5 & 34 & 21 & 60 & 4.27 \\
X1.8 & 0 & 4 & 17 & 30 & 9 & 60 & 3.73 \\
X1.9 & 0 & 3 & 24 & 33 & 0 & 60 & 3.5 \\
X1.10 & 0 & 0 & 3 & 32 & 25 & 60 & 4.37 \\
X1.11 & 0 & 1 & 18 & 29 & 12 & 60 & 3.87 \\
X1.12 & 0 & 0 & 17 & 37 & 6 & 60 & 3.82 \\
\hline
\end{tabular}

Sumber: Data Penelitian, 2020

Pada Tabel 5, dapat diketahui nilai rata-rata untuk tiap pernyataan yang didapat dari total skor responden pada sifat independensi. Untuk pernyataan responden yang memiliki skor diatas skor rata-rata dapat dikatakan bahwa pengawas internal tersebut memiliki sifat independensi yang tinggi.

Tabel 5. Statistik Deskriptif Independensi

\begin{tabular}{llllllll}
\hline \multicolumn{7}{c}{ Independensi } \\
\hline Kategori Pernyataan & STS & TS & N & S & SS & Total & Rata-rata \\
\hline X2.1 & 0 & 3 & 6 & 37 & 14 & 60 & 4.03 \\
X2.2 & 0 & 2 & 4 & 40 & 14 & 60 & 4.10 \\
X2.3 & 0 & 2 & 8 & 38 & 12 & 60 & 4.00 \\
X2.4 & 0 & 2 & 7 & 34 & 17 & 60 & 4.10 \\
X2.5 & 0 & 0 & 2 & 34 & 24 & 60 & 4.37 \\
X2.6 & 0 & 0 & 2 & 32 & 26 & 60 & 4.40 \\
X2.7 & 0 & 0 & 4 & 27 & 29 & 60 & 4.42 \\
\hline
\end{tabular}

Sumber: Data Penelitian, 2020

Pada Tabel 6, dapat diketahui nilai rata-rata untuk tiap pernyataan yang didapat dari total skor responden pada pengungkapan fraud. Untuk pernyataan responden yang memiliki skor diatas skor rata-rata dapat dikatakan bahwa pengawas internal tersebut memiliki kemampuan dalam mengungkapkan fraud yang tinggi.

Uji Normalitas bertujuan untuk menguji apakah dalam sebuah model regresi, variabel terikat dan variabel bebas atau keduanya memiliki distribusi normal atau tidak. Model penelitian yang baik adalah model penelitian yang memiliki distribusi data yang normal. Berikut merupakan hasil uji normalitas penelitian ini. 
Pada Tabel 7, dapat diketahui bahwa nilai Asymp. Sig (2-tailed) sebesar 0,305 yang lebih besar dari nilai signifikan 0,05 yang berarti seluruh data dalam penelitian berdistribusi normal.

Tabel 6. Statistik Deskriptif Pengungkapan Fraud

\begin{tabular}{llllllll}
\hline & \multicolumn{7}{l}{ Pengungkapan Fraud } \\
\hline Kategori Pernyataan & STS & TS & N & S & SS & Total & Rata-rata \\
\hline Y.1 & 0 & 1 & 10 & 43 & 6 & 60 & 3.9 \\
Y.2 & 0 & 0 & 2 & 47 & 11 & 60 & 4.2 \\
Y.3 & 0 & 1 & 11 & 42 & 6 & 60 & 3.9 \\
Y.4 & 0 & 0 & 6 & 41 & 13 & 60 & 4.1 \\
Y.5 & 0 & 0 & 8 & 43 & 9 & 60 & 4 \\
Y.6 & 0 & 1 & 5 & 44 & 10 & 60 & 4.1 \\
Y.7 & 0 & 0 & 4 & 27 & 29 & 60 & 4.4 \\
\hline
\end{tabular}

Sumber: Data Penelitian, 2020

Uji Multikolinearitas bertujuan untuk menguji apakah dalam model regresi terdapat hubungan multikolinearitas diantara variabel bebas (independen) atau tidak. Model regresi yang baik tidak terjadi multikolinearitas diantara variabel bebasnya. Berikut merupakan hasil uji multikolinearitas penelitian ini.

Tabel 7. Hasil Uji Normalitas

\begin{tabular}{llc}
\hline Model & $\mathrm{N}$ & Asymp. Sig (2-tailed) \\
\hline Model Regresi I & 60 & 0.305 \\
\hline Sumber:
\end{tabular}

Sumber: Data Penelitian, 2020

Pada Tabel 8, dapat diketahui bahwa nilai Tolerance kedua variabel bebas adalah sebesar 0,646 dan nilai VIF kedua variabel sebesar 1,548. Nilai tersebut lebih besar dari nilai Tolerance sebesar 0,10 dan lebih kecil dari nilai VIF sebesar 10,00 sehingga diketahui antara dua variabel bebas tidak terjadi multikolinearitas.

Tabel 8. Hasil Uji Multikolinearitas

\begin{tabular}{lll}
\hline Variabel & Tolerance & VIF \\
\hline Skeptisme Profesional & 0.646 & 1.548 \\
Independensi & 0.646 & 1.548 \\
\hline
\end{tabular}

Sumber: Data Penelitian, 2020

Uji heteroskedastisitas bertujuan untuk menguji apakah dalam model regresi terjadi ketidaksamaan variance dari residual satu pengamatan ke pengamatan lainnya. Model regresi yang baik adalah model regresi yang tidak terdapat gejala heteroskedastisitas. Berikut merupakan hasil uji heteroskedastisitas penelitian ini:

Tabel 9. Hasil Uji Heteroskedastisitas

\begin{tabular}{lll}
\hline Variabel & Sig & Kesimpulan \\
\hline Skeptisme Profesional & 0.717 & Tidak Terjadi Heteroskedastisitas \\
Independensi & 0.933 & Tidak Terjadi Heteroskedastisitas \\
\hline
\end{tabular}

Sumber: Data Penelitian, 2020

Pada Tabel 9, dapat diketahu bahwa nilai signifikan kedua variabel sebesar 0,717 dan 0,933 yang lebih besar dari nilai signifikan 0,05 yang berarti tidak ada gejala heteroskedastisitas dalam penelitian ini.

Nilai konstanta untuk pengujian ini bernilai 13,410 memiliki sifat positif yang artinya walaupun pengawas internal tidak skeptis dan tidak independen, pengawas internal tersebut tetap dapat mengungkapkan fraud. Nilai koefisien skeptisme profesional sebesar 0,087 memiliki sifat yang positif yang artinya bahwa 
skeptisme profesional berpengaruh positif pada kemampuan pengawas internal dalam mengungkapkan fraud. Nilai koefisien independensi sebesar 0,370 memiliki sifat yang positif yang artinya bahwa independensi berpengaruh positif pada kemampuan pengawas internal dalam mengungkapkan fraud.

$$
\hat{Y}=13,410+0,087 X_{1}+0,370 X_{2}+\varepsilon
$$

Berikut merupakan hasil dari teknis analisis regresi linear berganda penelitian.

Tabel 10. Analisis Regresi Linear Berganda

\begin{tabular}{|c|c|c|c|c|c|}
\hline \multirow[t]{2}{*}{ Model } & \multicolumn{2}{|c|}{$\begin{array}{l}\text { Unstandardized } \\
\text { Coefficients }\end{array}$} & $\begin{array}{l}\text { Standardized } \\
\text { Coefficients }\end{array}$ & $\mathrm{t}$ & Sig. \\
\hline & $\mathrm{B}$ & Std. Error & Beta & & \\
\hline 1 (Constant) & 13.41 & 2.967 & & 4.52 & 0 \\
\hline Skeptisme Profesional & 0.087 & 0.072 & 0.159 & 1.204 & 0.234 \\
\hline Independensi & 0.37 & 0.101 & 0.487 & 3.682 & 0.001 \\
\hline Adjusted R Square & & 0.333 & & & \\
\hline F Hitung & & 15.699 & & & \\
\hline Sig. F hitung & & 0.000 & & & \\
\hline
\end{tabular}

Sumber: Data Penelitian, 2020

Pada Tabel 10, dapat diketahui nilai signifikansi dari model sebesar 0,000 yang lebih kecil dari tingkat signifikansi yang ditetapkan sebesar 0,05 $(0,000<$ $0,05)$. Dari data tersebut dapat diketahui bahwa skeptisme profesional dan independensi pengawas internal memiliki kemampuan untuk menerangkan variasi kemampuan pengawas internal dalam mengungkapan fraud sehingga model tersebut dapat dikatakan layak untuk dilakukan penelitian. Selain itu terdapat nilai adjusted $R$ square sebesar 0,333 yang berarti bahwa besarnya kemampuan skeptisme profesional dan independensi pengawas internal untuk menerangkan variasi kemampuan pengawas internal dalam mengungkapan fraud adalah sebesar 0,333 atau 33,3\%.

Pada Tabel 10, didapatkan hasil $t_{\text {hitung }}$ dari variabel skeptisme profesional sebesar 1.204 dengan tingkat signifikansi sebesar 0,234 . Nilai $t_{\text {hitung }}$ tersebut lebih kecil dari nilai $t_{\text {tabel }}$ yang ditetapkan sebesar 2,002 $(1,204<2,002)$ dan tingkat signifikansinya lebih besar dari taraf signifikansi yang ditentukan yaitu 5\% $(0,234$ $>0,05$ ). Hal ini menunjukkan bahwa variabel skeptisme profesional tidak berpengaruh signifikan pada kemampuan pengawas internal dalam mengungkapkan fraud pada hotel berbintang 3 ke atas di Kabupaten Badung Selatan.

Hasil dari penelitian ini berbeda dengan penelitian yang dilakukan oleh Hartan (2016) dan Biksa (2016). Hartan (2016) menemukan bahwa skeptisme profesional auditor berpengaruh positif dan signifikan terhadap kemampuan auditor mendeteksi kecurangan pada Inspektorat Daerah Istimewa Yogyakarta. Perbedaan tersebut mungkin disebabkan oleh objek penelitian. Penelitian yang dilakukan oleh Biksa (2016) juga menyatakan bahwa skeptisme profesional auditor berpengaruh positif pada pendeteksian kecurangan di KAP. Perbedaan tersebut mungkin disebabkan oleh perbedaan objek penelitian dan perbedaan sifat instansi. Penelitian yang dilakukan oleh Hartan (2016) mengenai kemampuan auditor mendeteksi kecurangan di Inspektorat Daerah Istimewa Yogyakarta, 
merupakan lembaga sektor publik mewajibkan auditor internalnya bekerja sesuai peraturan yang berlaku secara umum sedangkan pengawas internal sebagai auditor yang bekerja dalam hotel yang merupakan lembaga sektor swasta lebih menekankan pada prosedur yang ditetapkan oleh hotel secara internal. Penelitian yang dilakukan oleh Biksa (2016) yang juga menyatakan bahwa skeptisme profesional auditor berpengaruh positif pada pendeteksian kecurangan di KAP. Penelitian yang dilakukan oleh Biksa pada kemampuan auditor mendeteksi kecurangan di KAP berbeda dengan penelitian ini karena KAP memiliki auditor yang bersifat eksternal yang melakukan pengauditan pada beberapa lembaga atau usaha yang menyewa jasanya sehingga dalam melakukan pengauditan memerlukan standar prosedur yang berlaku secara umum dan sesuai undangundang sedangkan pengawas internal yang bekerja pada hotel merupakan auditor yang bersifat internal dan dalam melakukan pengauditan menggunakan standar prosedur yang ditetapkan oleh hotel secara internal.

Temuan penelitian ini memberikan bukti empiris terhadap Teori Segitiga Kecurangan (Fraud Triangle Theory) yang diciptakan oleh Cressey (1953) yaitu pada aspek tekanan (pressure) yang menyatakan bahwa fraud terjadi sebagai akibat adanya tekanan pihak internal dan eksternal. Tidak berpengaruhnya skeptisme profesional pada pengungkapan fraud oleh pengawas internal pada hotel berbintang 3 ke atas di Kabupaten Badung Selatan mengindikasikan bahwa pengawas internal mendapatkan tekanan akibat hubungan sosial dan pertemanan yang terpola dalam bentuk budaya saling mempercayai.

Pada Tabel 10, didapatkan hasil $t_{\text {hitung }}$ dari variabel independensi auditor sebesar 3,682 dengan tingkat signifikansi sebesar 0,001. Nilai $t_{\text {hitung }}$ tersebut lebih besar dari nilai $t_{\text {tabel }}$ yang ditetapkan sebesar $2,002(3,682>2,002)$ dan tingkat signifikansinya lebih kecil dari taraf signifikansi yang ditentukan yaitu $0,05(0,001$ $<0,05)$. Hal ini menunjukkan bahwa variabel independensi berpengaruh signifikan pada kemampuan pengawas internal dalam mengungkapkan fraud pada hotel berbintang 3 ke atas di Kabupaten Badung Selatan.

Hasil dari penelitian ini mendukung penelitian yang dilakukan oleh Hartan (2016) yang menyatakan bahwa independensi auditor berpengaruh positif dan signifikan pada kemampuan auditor mendeteksi kecurangan pada Inspektorat Daerah Istimewa Yogyakarta dan penelitian yang dilaukan oleh Tobe (2017) yang menyatakan bahwa independensi auditor terbukti berpengaruh terhadap pendeteksi kecurangan pada KAP di Kota Bandung. Dapat diketahu bahwa semua pengawas atau auditor baik yang bersifat internal maupun publik dalam melaksanakan tugas audit selalu mempertahankan sifat independensinya dan tidak terpengaruh oleh pihak lainnya.

Hasil penelitian ini memberikan bukti empiris pada berlakunya Teori Perilaku yang Direncanakan (Theory of Planned Behavior) yang diciptakan oleh Ajzen (1991) dimana seseorang cenderung berperilaku sesuai dengan norma subyektif (subjective norm). Seorang pengawas internal walaupun dihubungkan dengan hubungan kekerabatan dengan objek pemeriksaannya, dalam penelitian ini terbukti mampu terlepas dari pola hubungan kekerabatan tersebut dan tetap konsisten pada berperilaku normatif seorang pengawas internal untuk bertindak secara independen. Hasil penelitian ini juga mengkonfirmasi berlakunya Teori Atribusi (Attribution Theory) yang diciptakan oleh Heider (1958) yang menjelaskan 
bahwa adanya penyebab internal ataupun eksternal untuk mendorong seseorang dalam melakukan suatu tindakan. Dimana dalam penelitian ini seorang pengawas internal harus selalu mempertahankan sikap independensinya yang merupakan faktor internal dari pengawas dalam melakukan proses auditing dan mengesampingkan faktor eksternal dari pengawas internal tersebut seperti hubungan kekerabatan atau pertemanan dengan objek audit.

\section{SIMPULAN}

Berdasarkan hasil dan pembahasan dalam penelitian ini maka dapat ditarik kesimpulan yaitu skeptisme profesional tidak berpengaruh signifikan pada kemampuan pengawas internal dalam mengungkapkan fraud pada hotel berbintang 3 ke atas di Kabupaten Badung Selatan dan independensi berpengaruh signifikan pada kemampuan pengawas internal dalam mengungkapkan fraud pada hotel berbintang 3 ke atas di Kabupaten Badung Selatan.

Berdasarkan pembahasan dan kesimpulan di atas maka peneliti dapat memberikan saran bagi pengawas internal, sebaiknya pengawas internal lebih mengembangkan sikap skeptisnya dengan berhati-hati dalam menilai suatu bukti keuangan karena pengawas internal memiliki kewajiban untuk menjaga kepercayaan para pihak yang berhubungan dengan laporan keuangan. Bagi manajemen atau perusahaan, sebaiknya pihak manajemen dan perusahaan memberikan akses kepada pengawas internal untuk memperoleh semua bukti keuangan yang diperlukan dalam melakukan proses auditing agar hasil keputusan laporan keuangan relevan dengan keadaan sebenarnya. Bagi perkembangan ilmu akuntansi, hasil penelitian ini diharapkan dapat menambah ilmu pengetahuan dan wawasan serta dapat memperkaya kepustakaan mengenai pengaruh skeptisme profesional dan independensi pada kemampuan pengawas internal yang dapat digunakan sebagai refrensi untuk penelitian selanjutnya. Bagi peneliti selanjutnya, sebaiknya penelitian ini dilanjutkan dengan menambah pemetaan responden dengan memperluas wilayah penelitian dan menggeneralisasi kriteria perhotelan yang dijadikan responden dalam penelitian selanjutnya. Dengan menggeneralisasi hotel, maka data yang didapat bervariasi dan penelitian dapat menggambarkan kinerja pengawas internal pada hotel secara keseluruhan.

\section{REFERENSI}

(ACFE), A. of C. F. E. (2016). Report to the Nations on Occupational Fraud and Abuse. Retrieved from https:// www.google.com/url?sa=t\&rct=j\&q=\&esrc=s\&source=web\&cd=\& ved=2ahUKEwi03eyqpbrqAhWVT30KHXnQDyoQFjAAegQIAhAB\&url=htt ps $\% 3 \mathrm{~A} \% 2 \mathrm{~F} \% 2 \mathrm{Fwww}$.acfe.com $\% 2 \mathrm{Frttn} 2016 \% 2 \mathrm{Fdocs} \% 2 \mathrm{~F} 2016$-report-to-thenations.pdf\&usg=AOvVaw2fL2VPEmJdE0KtiXsJVuua

(AICPA), A. I. of C. P. A. (2002). Statement Auditing Standart. Retrieved from https: / $w$ ww.google.com/url? sa $=$ t\&rct $=\mathrm{j} \& q=\&$ esrc $=$ s\&source=web\&cd $=\&$ ved=2ahUKEwjqtv27p7rqAhUFSX0KHTmkD5oQFjAAegQIBRAB\&url=http s\%3A\%2F\%2Fwww.aicpa.org\%2FResearch\%2FStandards\%2FAuditAttest \% 2FDownloadableDocuments \%2FAU- 
00316.pdf\&usg=AOvVaw2NYoY718J0tlZPjNa-PNRG

Ajzen, I. (1991). From Intentions To Actions: A Theory of Planned Behavior. Retrieved from https:/ /link.springer.com/chapter/10.1007/978-3-642-69746-3_2

Alvin A. Arens, Randal J. Elder, M. S. B. (2012). Auditing and assurance services : an integrated approach (14th ed.). Retrieved from https://trove.nla.gov.au/work/10114341

Andriyanti, D., \& Latrini, M. Y. (2019). Pengaruh Pengalaman, Independensi, dan Profesionalisme Auditor Internal Dalam Mencegah Kecurangan Pada Bank Perkreditan Rakyat. E-Jurnal Akuntansi, 27, 476. https:// doi.org/10.24843/eja.2019.v27.i01.p18

Biksa, Ida Ayu Indira, dan Wiratmaja, I. D. N. (2016). Pengaruh Pengalaman, Independensi, Skeptisme Profesional Auditor Pada Pendeteksian Kecurangan. E-Jurnal Akuntansi Universitas Udayana, Vol.17.3., 2384-2415. https:// doi.org/ISSN: 2302-8556

Christiawan, Y. J. (2002). Kompetensi Dan Independensi Akuntan Publik: Refleksi Hasil Penelitian Empiris. Akuntansi Dan Keuangan, 4(2), 79-92. https:// doi.org/https://doi.org/10.9744/jak.4.2.pp.\%2079-92

Cressey, D. R. (1953). Fraud Triangle. Literatur Profesional SAS, 99.

Ghozali, I. (2016). Aplikasi Analisis Multivariate Dengan Program IBM SPSS 23 (8th ed.). Semarang: Badan Penerbit Universitas Diponegoro.

Halim, A. (2003). Auditing 1 Dasar-dasar Audit Laporan Keuangan. Unit Penerbit dan Percetakan AMP YKPN.

Hartan, T. H. (2016). Pengaruh Skeptisme Profesional, Independensi Dan Kompetensi Terhadap Kemampuan Auditor Mendeteksi Kecurangan (Studi Empiris Pada Inspektorat Daerah Istimewa Yogyakarta). Universitas Negeri Yogyakarta. Retrieved from http://journal.student.uny.ac.id/ojs/index.php/profita/article/view/5626

Heider, F. (1958). The Psychology of Interpersonal Relations. New York: Wiley.

IAPI. (2012a). SA 240 Tnggung Jawab Auditor Terkait Dengan Kecurangan Dalam Suatu Audit Atas Laporan Keuangan. 05. Jakarta: Institut Akuntan Publik Indonesia.

IAPI. (2012b). SA 315 Pengidentifikasian Dan Penilaian Risiko Kesalahan Penyajian Material Melalui Pemahaman Atas Entitas Dan Lingkungannya. Jakarta.

Ivana, Almira dan Marsenda, P. H. (2018). MAKALAH PENELITIAN KAUSAL KOMPARATIF ( EX POST FACTO). Bandung.

Jusup, A. H. (2014). Auditing (Pengauditan Berbasis ISA) (2nd ed.). Yogyakarta: Bagian Penerbitan Sekolah Tinggi Ilmu Ekonomi YKPN.

Keputusan Menteri Parpostel No KM 94/HK103/MPPT 1987. (n.d.). No Title.

Mulyadi. (2010). Auditing Buku 1 (6th ed.). Jakarta: Salemba Empat.

Ponamon, I. F. (2014). Pengaruh Pengawasan Internal, Pemahaman Sistem Akuntansi Keuangan, Dan Kapasitas Sumber Daya Manusia Terhadap Kualitas Informasi Laporan Keuangan Pemerintah Daerah Pada SKPD Pemerintah Kota Manado. Jurnal Riset Akuntansi, 9, 68-80. https:// doi.org/https:/ / doi.org/10.32400/gc.9.2.5060.2014

Purwanti, I. G. A. P. D. S. (2017). Pengaruh Auditor's Professional Skepticism, Red Flags, Beban Kerja Pada Kemampuan Auditor Dalam Mendeteksi Fraud (Studi Empiris pada Kantor Akuntan Publik Provinsi Bali). Universitas 
Udayana. https://doi.org/https://doi.org/10.24843/EJA.2017.v21.i02.p11

Sawyer, B. Lawrence, Dittenhofer, M. and J. H. S. (2005). Sawyer's Internal Auditing (1st ed.). Jakarta: Salemba Empat.

Sugiyono. (2016). Metode Penelitian Pendekatan Kuantitatif Kualitatif dan RED. Bandung: Alfabeta.

Suryabrata, S. (2006). Metodologi Penelitian. Yogyakarta: PT Raja Grafinda Persada.

Suryanto, Rudy., Indriyani, Yosita., Sofyani, H. (2017). Determinan Kemampuan Auditor dalam Mendeteksi Kecurangan. Jurnal Akuntansi Dan Investasi, 18, No. 1, 103. https://doi.org/10.18196/jai.18163

Susilawati, \& Atmawinata, M. R. (2014). Pengaruh Profesionalisme Dan Independensi Auditor Internal Terhadap Kualitas Audit (Studi Pada Inspektorat Provinsi Jawa Barat). Jurnal Etikonomi. Retrieved from https:// doi.org/10.15408/etk.v13i2.1886

Tobe, I. F. (2017). Pengaruh Pengalaman Auditor Dan Independensi Auditor Terhadap Pendeteksian Kecurangan (Survei Pada Kantor Akuntan Publik Di Wilayah Bandung). Universitas Komputer Indonesia. Retrieved from https://elib.unikom.ac.id/download.php?id=355415

Wijaya, E. (2016). Penerapan Audit Investigatif Dalam Pengungkapan Fraud ( Studi Kasus Berkas Perusahaan X di Kepolisian RI). Widyatama Repository. Retrieved from http:/ / repository.widyatama.ac.id/xmlui/handle/123456789/6986 